\title{
ЗАБЕЗПЕЧЕННЯ ПРАКТИЧНОЇ ПІДГОТОВКИ ФАХІВЦІВ У ДОНЕЦЬКОМУ НАЦІОНАЛЬНОМУ МЕДИЧНОМУ УНІВЕРСИТЕТІ ім. М. ГОРЬКОГО
}

\author{
Ю. В. Думанський, Б. Б. Івнсв, М. Б. Первак
}

Донечький національний медичний університет ім. М. Горького

\section{PROVIDING DOCTORS' PRACTICAL TRAINING AT M. HORKYI DONETSK NATIONAL MEDICAL UNIVERSITY}

\author{
Yu. V. Dumanskyi, B. B. Ivnyev, M. B. Pervak \\ Donetsk National Medical University by M. Horkyi
}

\begin{abstract}
У статті висвітлено досвід Донецького національного медичного університету ім. М. Горького із забезпечення практичної підготовки фахівців на до- та післядипломному рівнях навчання. Визначено організаційно-методичні аспекти цього виду навчання, наведено комплекс реалізованих та запланованих заходів, спрямованих на підвищення його ефективності.
\end{abstract}

The article adduces the experience of M. Horkyi Donetsk National Medical University in providing the doctors' practical training at pre-graduate and post-graduate levels of education. Organizing and methodical aspects of this kind of training were determined. The complex of realized and planned measures directing at improving of its effectiveness was proposed.

Вступ. Головною метою реформування вітчизняної системи охорони здоров'я, яке проводиться в Україні, $є$ суттєве поліпшення якості надання медичної допомоги населенню країни. Досягнення цієї мети неможливе без значного підвищення рівня медичної освіти - як на додипломному, так і на післядипломному їі етапах [2]. Останнім часом представниками багатьох медичних вищих навчальних закладів (ВН3) як в доповідях, так і в публікаціях було відзначено збільшення питомої ваги теоретичної складової у підготовці медичних фахівців, обумовлене цілою низкою різних чинників. Серед них як гонитва за кращими результатами ліцензійних тестових іспитів, так i об'єктивні обставини, а саме: недостатнє фінансування ВН3 для забезпечення навчання малими групами, проблеми з виробничою практикою, що виникли останніми роками, неврегульованість правових аспектів залучення пацієнтів до навчального процесу, інколи відсутність тематичних хворих тощо. У Донецькому національному медичному університеті ім. М. Горького (ДонНМУ) проблема підвищення якості практичної підготовки студентів вперше постала гостро у 2010 році, коли на випускаючі кафедри прийшли “вихованці" кредитно-модульної системи [1]. Для зміни ситуації на краще керівництвом нашого ВНЗ у тому ж навчальному році було розроблено та розпочато низку відповідних заходів.

() Ю. В. Думанський, Б. Б. Івнєв, М. Б. Первак
Основна частина. Перш за все, на базі вимог чинних державних стандартів медичної освіти [5] та відповідно до реалізованої у ДонНМУ системи управління якістю підготовки фахівців $[3,4,6]$ для всіх медичних спеціальностей, за якими у нашому ВН3 проводиться навчання на додипломному рівні (“Лікувальна справа”, "Педіатрія", “Медико-профілактична справа”, “Стоматологія”)' було розроблено наскрізні програми практичної підготовки. В останніх не лише сформовано перелік практичних навичок, необхідних для майбутнього лікаря, але й напроти кожної $з$ них зазначено конкретні кафедри та практики, що відповідають за ії освоєння та закріплення.

Для реалізації означених вище наскрізних програм з 1 вересня 2011 р. у ДонНМУ було відновлено забуту при впровадженні кредитно-модульної системи практику атестації практичної підготовки майбутніх лікарів. Основним механізмом ії стало ведення індивідуальних планів студентів з цього виду навчання. Вони є обов'язковим документом для всіх студентів стоматологічного та медичних факультетів.

Кожній 34 спеціальностей відповідає окремий індивідуальний план, який складається 33 розділів - таких, як: 1) наскрізна програма практичних навичок 3 певної спеціальності; 2) облік освоєння практичних навичок на конкретних кафедрах; 3) облік освоєння практичних навичок під час виробничої практики - по 
курсах і профілях. Важливим, на нашу думку, є те, що на кожному етапі проти кожної навички зазначено так звану мінімальну кількість разів правильного виконання. Лише за умови, що за період навчання з цієї дисципліни (або під час практики) студент продемонстрував викладачу володіння цією навичкою у кількості разів, не менш за мінімальну, викладач напроти неї зазначає своє прізвище та ставить підпис. Як свідчить наш досвід, це сприяє підвищенню відповідальності кафедр і окремих викладачів за цей вид роботи.

У розділі “навчання на кафедрах" всі практичні навички розподілені на дві групи: такі, що можуть бути освоєні лише при роботі з пацієнтом, і такі, що на першому етапі можуть бути освоєні при роботі 3 тренажерами, фантомами, муляжами тощо.

Для підвищення рівня освоєння студентами другої групи практичних навичок керівництвом нашого університету у 2011-2012 н. р. було організовано окремий Центр практичної підготовки студентів (далі Центр) загальною площею близько 150 кв. м. Його діяльність, а також співпрацю з кафедрами та іншими структурними підрозділами університету регламентовано окремим Положенням, затвердженим ректором.

Базуючись на одному з основних положень педагогіки, що для якісного освоєння будь-якого вміння необхідне його неодноразове повторення, ми плануємо, що у створеному Центрі будуть проходити навчання студенти 3-5 курсів всіх медичних факультетів.

Наразі у Центрі у повному обсязі працюють 4 відділення - терапевтичне, хірургічне, педіатричне та акушерсько-гінекологічне, в яких освоюють навички відповідного профілю студенти 3-4 курсів. Всі відділення забезпечені необхідними тренажерами та муляжами, на придбання яких університетом було витрачено за два роки 400 тис. гривень.

Заняття у Центрі практичної підготовки відбуваються за окремим розкладом. Кожна група студентів означених вище курсів щонайменше двічі за період вивчення певної дисципліни приходить до Центру. На першому занятті викладач та співробітник відповідного відділення Центру навчають студентів необхідних практичних навичок, показуючи їм правильне виконання та корегуючи у кожного студента процес освоєння навички. На другому занятті перед підсумковим модульним контролем викладач перевіряє рівень володіння цими навичками у кожного студента групи та при позитивному результаті робить відповідний запис у його індивідуальному плані практичної підготовки.

Навчання студентів у Центрі є об'єктом постійного моніторингу з боку навчально-методичного відділу.
Результати цього моніторингу наприкінці кожного семестру подаються ректору та першому проректору для оптимізаціі роботи Центру.

Студенти стоматологічного факультету опановують необхідними їм практичними навичками на тренажерах та фантомах у так званому фантомному залі на базі кафедри пропедевтичної стоматології.

Як було зазначено вище, крім роботи у Центрі та фантомному залі, в індивідуальних планах практичної підготовки студентів передбачено оволодіння ними практичними навичками при навчанні на клінічних базах та під час практики при роботі з реальними об'єктами лікарської діяльності - пацієнтами.

Для перевірки та можливої корекції рівня практичної підготовки студентів 6 курсу медичних факультетів та 5 курсу стоматологічного факультету наразі проводиться оснащення всіма необхідними тренажерами та муляжами випускаючих кафедр. Планується проведення атестації практичної підготовки випускників перед складанням ними практично-орієнтованих іспитів.

Природно, що ефективність всіх заходів можна буде оцінити лише через декілька років. Але для визначення, умовно кажучи, “точки відліку” нами наприкінці 2011-2012 н. р. було проведено дослідження з визначення рівня практичної підготовки випускників цього року як за матеріалами державних практичноорієнтованих іспитів, так і за результатами соціологічного опитування.

Для останнього було розроблено спеціальні анкети, які для випускників медичних факультетів містили 55 практичних навичок, для випускників стоматологічного факультету - 82 (суто стоматологічні та загальнолікарські). Опитано 220 студентів 6 курсу медичних факультетів та 130 студентів стоматологічного. Проти кожної з навичок респондент мав зазначити "рівень знайомства" з нею: бачив, як виконує викладач; виконував самостійно на клінічних кафедрах при роботі з муляжами, фантомами (кількість разів), при обстеженні пацієнтів (кількість разів); під час виробничої практики (кількість разів).

Результати опитування окремого респондента були порівняні з вимогами, означеними в індивідуальних планах практичної підготовки студентів. Зокрема, зіставляли зазначену опитуваними кількість разів виконання певної навички під час навчання на різних клінічних кафедрах (при роботі з муляжами, фантомами та при дослідженні пацієнтів) та під час виробничої практики, із кількістю, що встановлена як мінімальна.

Рівень оволодіння навичкою вважали високим, якщо від 75 до $100 \%$ респондентів зазначили кількість разів 
виконання не менш за мінімальну, середнім - якщо зазначена кількість була достатньою у 50-74 \% опитаних і низьким - якщо частота позначення достатньої кількості разів була меншою за 50 \%. У студентів 6 курсу медичних факультетів виявлено високий рівень оволодіння більшістю практичних навичок, які реалізуються при фізикальному обстеженні пацієнтів: перкусія та аускультація легень, серця, пальпація судин, живота, молочних залоз, визначення частоти пульсу тощо (від 75 до $100 \%$ респондентів зазначили кількість разів виконання не менш мінімальної). Втішною виявилася і ситуація з більшістю акушерських навичок: для вимірювання розмірів таза, зовнішнього акушерського обстеження вагітних за Леопольдом, визначення маси плода зазначена кількість разів лише у 25 \% опитуваних була меншою, ніж мінімальна. Низьким рівень засвоєння, за даними соціологічного дослідження, виявився для таких практичних навичок, як ін'єкції лікарських речовин, особливо внутрішньовенних, промивання шлунка, кишечника, визначення групи крові стандартними сироватками та визначення резус-приналежності, пальцеве дослідження прямої кишки, катетеризація сечового міхура м'яким зондом. Можливо, це значною мірою зумовлене наявністю останнім часом проблем з повноцінним проведенням виробничої практики. Для всіх інших навичок рівень володіння у випускників медичних факультетів, за даними анкетування, виявився середнім.

Соціологічне опитування випускників стоматологічного факультету показало достатній рівень володіння суто стоматологічними навичками та низький більшістю загальнолікарських маніпуляцій. Можливо,

\section{Література}

1. Думанський Ю. В. Освоєння студентами практичних навичок при кредитно-модульній організації навчального процесу: проблеми та пошук шляхів їх вирішення / Ю. В. Думанський, О. М. Талалаєнко, М. Б. Первак // Нові напрямки впровадження кредитно-модульної системи організації навчального процесу у вищих медичних і фармацевтичному навчальних закладах України III-IV рівнів акредитації : матеріали Всеукраїнської навчально-наукової конференції. - Тернопіль, 2011. - С. 31-33.

2. Інтеграція додипломної та післядипломної підготовки лікарів та провізорів - вимога успішної реалізації реформ у сфері охорони здоров'я / Р. О. Моісеєнко, О. К. Толстанов, О. П. Волосовець [та ін.]// Впровадження нових технологій за кредитно-модульної системи організації навчального процесу у ВМ(Ф)НЗ III-IV рівнів акредитації : матеріали Всеукр. навч.-наук. конф. - Тернопіль, 2012. - С. 1-4.

3. Методологія і реалізація системи управління якістю це обумовлено, перш за все, суб' єктивним чинником - вузькоспеціалізованою налаштованістю студентів цього факультету, починаючи з перших курсів.

Необхідно відзначити, що аналіз матеріалів практично-орієнтованих іспитів показав кращу картину. Рівень освоєння всіх практичних навичок, перевірених на цьому етапі підсумкової атестації, виявився достатнім.

У зв'язку з реформуванням вітчизняної системи охорони здоров' я та підвищенням ролі первинної ланки надання медичної допомоги цього навчального року ми поширили наш досвід організації та проведення навчання практичних навичок студентів на післядипломний рівень медичної освіти. На базі наскрізних програм практичної підготовки студентів медичних факультетів, що реалізуються, шляхом зіставлення їх 3 програмою практичного навчання i кваліфікаційними вимогами лікарів-інтернів за спеціальністю “Загальна практика- сімейна медицина” було розроблено проект індивідуального плану практичної підготовки в інтернатурі з вищеозначеної спеціальності, впровадження якого буде розпочато 31 вересня 2013 р. Крім того, на факультеті інтернатури та післядипломної освіти створено спільний тренінговий центр кафедр анестезіологіі, реаніматології та медицини невідкладних станів, акушерства, гінекології та перинатології ФППО, травматології, ортопедії та хірургії екстремальних ситуацій, педіатрії ФІПО, загальної практики - сімейної медицини, неонатології для навчання лікарів-інтернів практичних навичок.

Висновок. Вважаємо, що система практичної підготовки фахівців, яка розроблена та реалізується у нашому університеті, дозволить суттєво підвищити ефективність цього виду навчання.

медичної освіти / [В. М. Казаков, О. М. Талалаєнко, М. Г. Гаріна та ін.]. - Донецьк, 2001. -213 с.

4. Опыт управления учебной деятельностью студентов при реализации компетентностного подхода / [Ю. В. Думанский, В. Н. Казаков, А. Н. Талалаенко и др.]. - Москва, 2010. -64 c.

5. Складові галузевих стандартів вищої освіти напряму підготовки 1101 “Медицина” освітньо-кваліфікаційного рівня “спеціаліст” за спеціальностями "Лікувальна справа”, "Педіатрія", "Медико-профілактична справа". - Київ : Міністерство освіти і науки України, 2003. - 369 с.

6. Управление качеством подготовки специалистов: программно-целевой подход (на примере высшего и послевузовского медицинского образования) / [В. Н. Казаков, Н. А. Селезнева, А. Н. Талалаенко и др.]. - [2-е изд.]. - Москва, 2007. -215 с. 